\title{
De tillträdande redaktörerna har ordet
}

DetTa NUmmer aV Sociologisk Forskning är det sista numret från redaktionen i Lund, under ledning av redaktörerna Sara Eldén och Christofer Edling. Ett varmt tack till Lundaredaktionen för allt arbete som de har lagt ner på att göra en tidskrift som publicerat viktiga och relevanta artiklar och hållit det vetenskapliga samtalet i sociologsverige levande. Ett stort tack till de avgående redaktörerna för att de också sett till att tidskriften nu har ett fungerande manushanteringssystem, Open Journal Systems, samt för deras arbete med att stärka tidskriftens närvaro och tillgänglighet i olika digitala kanaler.

I det här numret har vi i den nya redaktionen bidragit med ett samtal om sociologiska perspektiv på coronakrisen. I samtalet diskuterar forskarna Erna Danielsson, Fredrik Liljeros, Shai Mulinari och Linda Soneryd bland annat betydelsen av sociologisk kunskap för samhällets hantering av kriser och risker, samt den dynamik mellan expertis, politiker och medborgare som präglar frågor där expertkunskap är centralt. Det handlar också om att uppmärksamma perspektiv som annars tenderar att falla bort i den allmänna debatten - såsom ojämlikhet, konflikter, makt och ideologi, vilket är något som Shai Mulinari lyfter fram i samtalet.

Tidskriften Sociologisk Forskning har flera viktiga uppgifter. Genom att publicera artiklar på svenska blir den sociologiska forskningen mer tillgänglig för en bredare publik i Sverige och kan få genomslag i det offentliga samtalet. I en tid då forskare alltmer uppmanas att ägna sig åt "den tredje uppgiften” måste det finnas goda möjligheter att kommunicera nya forskningsrön på det språk som dominerar det offentliga samtalet i Sverige. Vi ser det som en viktig uppgift att sprida tidskriftens texter till en bredare publik, något som underlättas av tidskriftens övergång till att vara öppet tillgänglig via internet. Detta gynnar inte bara forskare, utan även personer utanför akademin. Att aktivt sprida kvalitetssäkrad vetenskaplig kunskap till allmänheten är inte minst viktigt i en tid som präglas av "fake news", en ökad betydelse för icke-akademiska kunskapskällor och ett debattklimat där åsikter många gånger får företräde framför fakta.

Även om tidskriftens främsta uppgift är att publicera kollegialt granskade vetenskapliga artiklar på svenska ser vi samtidigt fördelar med att i viss mån publicera engelskspråkiga artiklar. En engelsk språkdräkt möjliggör en ökad internationell spridning av sociologisk forskning om svenska samhällsförhållanden, vilket samtidigt kan bidra till större intresse för tidskriften även utanför det svenska och skandinaviska språkområdet. 
Vi återkommer med 2020 års andra nummer, vilket blir det första som helt komponeras av den nya redaktionen i vid Södertörns högskola.

De tillträdande redaktörerna,

Lena Sohl och Magnus Wennerhag 